\title{
Mechanism of Execution on Land and Building Auction Objects Proposed by the Auction Winner at the District Court
}

\author{
Awal Ratna Margasari Fence M. Wantu Dian Ekawati Ismail \\ State University of Gorontalo
}

\begin{abstract}
This study purpose to find out and analyze the mechanism of execution on land and building uction objects proposed by the auction winner at the District Court of Gorontalo and to find out and analyze the legal protection of the auction winner toward resistance to execution of mortgage rights at the District Court of Gorontalo. The study used normtive reserch method. The legal protection of the auction winner toward resistance to execution of mortgage rights at the District Court of Gorontalo has not appeared clearly in normative law however stated in several statutes such as the auction winner rights get aution minutes, uction winner as good buyer, the auction winner may get compensate if the auction being cancelled and the resistance ctully would not suspend the execution thus the auction winner get legal certainty.
\end{abstract}

Key terms :Execution, Auction Objects

DOI: $10.7176 / \mathrm{JLPG} / 98-15$

Publication date:June 30th 2020

\section{Introduction}

The Indonesian state is legal state having duty to protect its citizen to create order, safety, justice nd welfare in the society. In line with the economic development conducted by the government, the society will need finansial institutions and banking to support their economic activities. The finansial institutions will connect to debts and receivble, mortgage right, and if there is any bad credit, there will be auction, suing sue execution by the court. The legal protection toward the parties in the credit engagement following by execution auction of mortgage rights for the body integrity credit is arranged in the Act 6 of the Law number 4 of 1996 on The Mortgage Right of The Land including anythings related to the land, that if the debitor breach of contract, first mortgage right holder can immediately and directly submit an execution auction of mortgage right to the State Wealth and Service Office and take the payment of the receivable first from the auction. Then, the Act 14 of the Law number 4 of 1996 on The Mortgage Right of The Land including anythings related to the land describe on the basic of the execution auction by the District Court and the State Wealth and Service Office proposed by the mortgage right winner via claim. Next, the State Wealth and Service Office conduct the execution auction based on VenduReglement as the highest auction rule and the Finansial Ministry Regulation number 27/PMK.06/2016 dated 19 February 2016 on the Instruction of Auction as replacement of the Finansial Ministry Regulation number 61/PMK.06/2006, the Finansial Ministry Regulation number 93/PMK.06/2010 and the Finansial Ministry Regulation number 106/PMK.06/2013 that arranging on legal certainty for mortgage right holder as the auction applicant, grator of mortgage right or guarantor and also the buyer or auction winner. The definition of auction refer to selling goods followed by auction participants. The auction is conducted based on regulation of goods prices being sold announced by auction official or auctioneer. Based on the definition, the auction or general selling have elements, including buy and sell for public, preceded by auction announcement through some medis, such as newspaper in period of times, the price bargaining arranged by auction official or institution, the goods price of the highest bid. ${ }^{1}$ The buyer or auction winner has followed all the steps of auction then finally decided as the auction winner. Several characteristics of auction activities includebuilt in control, objective, competitive and authentic. The auction is "authentic". The reason would be the auction activity having conducted is arranged in the auction minutes or an authentic document where the buyer may use the document as proof that the selling activity has run based on auction procedure. The buyer may use the document or the deed as purchase proof for the need of transfer of title. ${ }^{2}$ In this case, the auction or selling goods conducted in front of public and officially in front of auction official and the conduct stated in auction of minutes will be occured transfer of wnership on the auction object. The transfer of right on the auction object from the seller to the buyer or the auction winner is legal effect of the auction. The transfer process of right on the auction goods will never run as it should be. The auction winner often face problem in the process of right transfer formally or materially. The formal transfer of right mean the auction winner cannot take control on the auction goods and moreover the auction winner must face claim or resistance from the debitor or the third party such as guarantor for loans owned by the debitor. 


\section{Mechanism of Execution on the Auction Objects Land and Building Proposed by the Auction Winner in the District Court}

The meaning of "mekanisme" according to Dictionary of Indonesian Langguage mean 1. The way of using machine; tools of machine; anything about machine work, 2.The way of an organization works (association and others), 3. Anything of work together such as machine (if one moves, the others do). ${ }^{1}$ Based on the definition, mechanism of execution mean the way of work or procedure conducted in execution, especially execution of auction objects land and building proposed by the auction winner to the District Court of Gorontalo. The court is institution authorizing and having duty to solve the crime or civil cases. The authority of court as stated in 50 of the Law number 8 of 2004 jo the Law number 49 of 2009 on the Second Changing on The Law Number 2 of 1986 on the Public Court namely the District Court with duty and authority to observe, decide, and solve crime and civil cases in the first level.

The execution conducted by the District Court of Gorontalo resulted from the judge decision with firm legal power and also resulted from execution proposal from the winner of the mortgage right auction based on the auction minutes.

The execution mechanism toward the auction object of mortgage right in the District Court based on the Guide of Execution at the District Court as follow:

1. The execution proposal is applied by the auction winner to the Leader of the District Court of Gorontalo.

The execution petition is applied writtenly to the District Court Leader signed by applicant principal or power of attorney by attaching special power of attorney. The petition include identities of applicant and respondent, domicile of the parties, quote of auction minutes, simple essay of the problem and the reason of the petition as well as petition object. The petition letter also include quote of auction minutes, ownership certificate of a single house or right od land auctioned or letter of statement from the Auction Office Leader on the reason for not distributing the certificate, proof of auction buyer idendity, proof of payment of purchsing price and resistance decisions as well as other letters if necessary.

2. The Warning of Execution (aanmaning)

The Leader of District Court issue the decision of execution warning or aanmaningafter exist execution application from execution applicant. It is in line with act $196 \mathrm{HIR}$ or act $207 \mathrm{RBg}$. The decision of warning execution cover an order to the clerk of court to point Bailiff or Replacement Bailiff to call the execution respondent and if necessary the execution applicant, using relaas call at latest in 3 (three) weekdays before the implementaion of aanmaning.

3. The Decision of Day and Date of Execution

The District Court Leader decide the day and date of execution stated in determination. Before decide the day and date of execution, to do real execution such as emptying, the District Court Leader conduct meeting of coordination together with safety apparatur. The District Court and the execution respondent do coordination first with local safety apparatur in line with the cost and time of execution. In this case, the clerk of court receive announcement of readiness from safety party related to time of execution. The clerk of court lead the technical coordination meeting on the execution implementation in the office of the District Court befor the execution.

4. The Announcement Before the Execution Day, The announcement of the execution day and date is conducted using relaas or letter of announcement to the execution respondent, execution applicant, and village leader. The announcement letter of the execution to the execution respondent must consider the adequate time of period from the announcement day to the execution day. The Clerk of court through the Bailiff or Resplacement Bailiff conduct annoucement at latest 3 (three) weekdays before the execution.

5. The Execution

The District Court Leader in period of not more than 8 (eight) weekdays after theaanmaningthat the execution respondent refuse to fulfill volunterly has authority to do execution. The execution is conducted by the Clerk of Court or Bailiff or the Replacement one with 2 (two) witnesses and accompany by safety officer.

6. The Minutes of Handover, After the emptying finish, the land and building are transfered to the execution applicant or the power of attorney on that day by recording in the Minutes of Handover witnessed by local apparatus. The duty of the Clerk of Court or Bailiff or the Replacement finish after the emptying and handover conducted, however, if necessary the execution applicant can ask to the safety apparatus to do tempore guarding toward the land and building being executed.

\section{Conclusion}

In line with the duty and authority of court institution, in this case the district court, the court obligate to observe, decide and solve any civil case proposed by disputing parties, that get solution or way out toward cases being disputed in form of decision. However, with a decision it does not meant that a case finish fully. It because there is step that must be conducted in order to apply the decision called execution. The execution process become unity

${ }^{1}$ kbbi.kemdikbud.go.id, accesed at 23 February 2020 at 20.23 WITA. 
with the judge decisionin form of finishing of civil case process related to someone duty and right in a case or dispute. The execution rule arrange how the court decision can be applied as result of existence of civil law violation. The definition of execution refer to conduct the court decision with firm legal power (res judicata/inkracht van gewijsde) and punishment (condemnatoir), conducted forcely if necessary with assistance of public power. In the civic case, the decision will have firm legal power if there is no appeal toward the first court decision, verstekdecision without any resistance (verzet), peaceful decision, appeal decision without cassacion, and there is no legal effort or cassacion decision such as judicial review, although in line with the Act 66 of the Law number 3 of 2009 on Supreme Court, legally judicial reviewdoes not delay the execution of decision.

\section{Reference}

Abdul Kadir Muhammad, 2004. Hukum dan Penelitian Hukum, Bandung: PT. Citra Aditya Abadi.

Ade Maman Suherman. 2004. Pengantar Perbandingan Sistem Hukum. Jakarta:RajaGrafindo Persada.

Amiruddin dan Zainal Asikin, 2013, Pengantar Metode Penelitian Hukum, Jakarta: Rajawali Pers.

Balitbang Diklat Kumdil Mahkamah Agung RI. 2007. Pedoman Teknis Administrasi dan Teknis Peradilan Umum, Buku II. Jakarta: Mahkamah Agung RI.

Bambang Sunggono. 2013, Metodologi Penelitian Hukum, Jakarta: RajaGrafindo Persada.

Burhan Sidabariba, 2019. Lelang Eksekusi Hak Tanggungan Meniscayakan Perlindungan Hukum bagi Para Pihak, Jakarta: Papas Sinar Sinanti.

Djazuli Bachar 1987.Eksekusi Putusan Perkara Perdata Segi Hukum dan Penegakan Hukum. Jakarta: Akademika Pressindo.

Faried Ali, Anwar Sulaiman, Femmy Silaswaty Faried, 2012. Studi Sistem Hukum Indonesia Untuk Kompetensi Bidang Ilmu-ilmu Sosial dan Ilmu Politik dan dalam Payung Pancasila, Bandung: Refika Aditama.

Fence M. Wantu, Mutia Cherawaty Thalib dan Suwitno Y. Imran, 2010, Cara Cepat Belajar Hukum Acara Perdata, Yogyakarta: Reviva Cendekia.

Friedman, Lawrence M. 1975. Sistem Hukum Prespektif Sistem Sosial. Terjemahan M. Khozim. Bandung: Nusa Media, Indonesia. 2018.

F. X. Ngadijarno, Nunung Eko Laksito dan Isti Indri Listiani, 2009, Lelang: Teori dan Praktik dalam Rachmadi Usman, 2016. Hukum Lelang. Jakarta: Sinar Grafika.

Herri Swantoro, 2018. Dilema Eksekusi. Jakarta: Rayyana Komunikasindo.

H. R. Otje Salman S. dan Anthon F. Susanto, 2015, Teori Hukum, Mengingat, Mengumpulkan, dan Membuka Kembali, Bandung: Refika Aditama.

Kelsen, Hans. 2008.Teori Umum Tentang Hukum dan Negara, Bandung: Nusa Media.

M. Yahya Harahap. 1997. Perlawanan Terhadap Eksekusi Grose Akta Serta Putusan Pengadilan dan Arbitrase dan Standar Hukum Eksekusi. Bandung: Citra Aditya Bakti.

Muchsin.2003. Perlindungan dan Kepastian Hukum bagi Investor di Indonesia. Surakarta:Magister Ilmu Hukum Program Pascasarjana Universitas Sebelas Maret.

Muhammad Nasir, 2003. Hukum Acara Perdata, Jakarta: Djambatan.

Munir Fuady.2007.Sosiologi Hukum Kontemporer: Interaksi Hukum, Kekuasaan, dan Masyarakat. Bandung: Citra Aditya Bakti.

Peter Mahmud Marzuki. 2016, Penelitian Hukum, Jakarta: Kencana Prenada Media Grup, Cetakan Ke-12.

Philipus M. Hadjon. 1987. Perlindungan Bagi Rakyat di Indonesia. Surabaya: PT.Bina Ilmu.

R. Soepomo, 2006, Hukum Acara Perdata, Cetakan Keenambelas, Jakarta: Pradnya Paramita.

Satjipto Rahardjo. 2014.Ilmu Hukum. Cetakan Ke XIV, Bandung: Citra Aditya Bakti.

Soerjono Soekanto dan Sri Mamudji, 2015, Penelitian Hukum Normatif Suatu Tinjauan Singkat, Jakarta: PT RajaGrafindo Persada.

Soerjono Soekanto. 2015, Pengantar Penelitian Hukum, Jakarta: UI Press, Cetakan Tahun 2015.

R. Subekti. 1989. Hukum Acara Perdata. Jakarta: Bina Cipta. 